\title{
On Cerebrospinal Fluid Immunoglobulin-G (IgG) Quotients in Multiple Sclerosis and other Diseases
}

\author{
A Review and a New Formula to Estimate the Amount of IgG \\ Synthesized per Day by the Central Nervous System
}

\author{
W. TOURTELLOTTE \\ Department of Neurology of the University of Michigan Medical Center, Ann Arbor, Mich. 48104 \\ (U.S.A.)
}

(Received 8 August, 1969)

\section{INTRODUCTION}

I have been asked numerous times why the cerebrospinal fluid (CSF) immunoglobulin-G (IgG) content has to be expressed as a percentage of the CSF total protein to be discriminative for multiple sclerosis (MS). From a historical standpoint, KABAT et al. (1950) found that the absolute value of CSF IgG (mg IgG/100 $\mathrm{ml} \mathrm{CSF)} \mathrm{was}$ elevated virtually every time when CSF total protein was significantly increased no matter which disease caused it; however, they discovered when the results were expressed as a ratio of the total protein, there emerged a pattern which discriminated MS from most other diseases. Eighty per cent of patients with MS had an elevated IgG value (IgG/total protein in $\%) \geqq 13 \%$ (mean +2 standard deviations, $P=0.05)$. In subsequent reports by the same group, YAHR et al. (1954) and HARTER et al. (1962) found 67 and $73 \%$ of patients with MS and neurosyphilis, respectively, had an elevated IgG value; whereas, only $5.5 \%$ of 7225 patients who had a neurological disease other than a demyelinating disorder (MS, diffuse sclerosis, acute disseminated encephalomyelitis, and neuromyelitis optica) and neurosyphilis had an elevated value.

It is not the purpose of this account to review in detail the incidence of abnormally elevated $\gamma$-globulin quantitatively determined in CSF from MS patients reported by various investigators; TOURTELlOTTE (1970) has recently done this. In general the multitude of reports utilizing very different methods have confirmed the results presented by KABAT and his colleagues mentioned above obtained with the reliable and valid immunochemical method of KABAT et al. (1948).

The quotients or ratios to be discussed are the following: IgG concentration expressed as a percentage of the total protein concentration; IgG concentration expressed as a percentage of the albumin concentration; IgG concentration expressed

Paper presented at a symposium on The Blood-Brain Barrier, held 11 September, 1968, in New York, N.Y.(U.S.A.).

This work was supported in part by Grant NB-05388 from the U.S. Public Health Service. 
as a percentage of the $\beta$-globulin concentration; and the CSF IgG concentration expressed as a percentage of the serum IgG concentration.

It is the purpose of this review to disclose the basis for the discriminative value for MS and the biologic significance of the various CSF IgG quotients by bringing together all the relevant recent advances of CSF physiology and some new aspects of the pathology of MS.

Finally, we will present a formula which estimates the amount of $\mathrm{IgG}$, expressed in mg, synthesized per day by the central nervous system (CNS) of MS patients. This calculation can be considered to be a substitute for the previous IgG quotients proposed since the basis of these quotients to discriminate MS from most other diseases turns out to be a de novo synthesis of IgG in the CNS of such cases.

\section{SINK ACTION OF THE CSF}

The CSF is unique among body fluids. This fluid not only fills the ventricles and surrounds the CNS but it also probably penetrates it by way of the Virchow-Robin spaces. Moreover, it is in close contact with but separated by a barrier from the blood supply of the CNS as well as from the blood and lymphatic supply of its covering membranes. TSCHIRGI (1960) was one of the first investigators to present some evidence to support the hypothesis that the CSF is a pool of circulating fluid in communication with the extracellular fluid (ECF) that surrounds the CNS cells; i.e. the CSF is in an expansion of the extracellular space (ECS), approximately $150 \mathrm{ml}$, which is filled with a type of "diluted" CNS ECF.

OLDENDORF (1967) has reviewed the literature and presented the data which have been accumulated to advance the argument that the CSF circulating through the ventricles and in the subarachnoid space at the rate of $500 \mathrm{ml} /$ day non-specifically clears solutes from the ECS of the CNS; i.e. the CSF constitutes a low-concentration compartment (a "sink") in widespread close contact with the CNS ECF, resulting in diffusion of solutes into the CSF. These solutes are then returned to the blood by bulk flow through the microtubular system of the arachnoid villi. It might be said that the sink action of the CSF serves the function of a lymphatic system adapted to the CNS. On the other hand, Davson AND Segal (1969) perfused the ventricles of rabbits with silicone instead of artificial CSF. The escape of $\left[{ }^{14} \mathrm{C}\right]$ sucrose, an extracellular space marker, from the CNS was largely prevented by replacement of CSF by silicone. The data suggested that the removal of ions by a flow mechanism from the ECS was relatively unimportant, since the silicone should carry away the "subsidiary fluid" as efficiently as CSF. They suggested that the mechanism for escape of solutes from the CNS ECS to CSF is simple diffusion through a stationary ECF.

The CSF is in contact with the ECS of the CNS by the ependyma and possibly the Virchow-Robin spaces. The ependyma behaves like a loosely-knit membrane presumably with large gaps between its cells; moreover, according to BRIGHTMAN (1965) it is permeable to large molecules, e.g., ferritin, 500,000 mol.wt. An easy exchange of solutes across the ependyma could be related to the composition of MS CSF, since BROWNELL AND HuGHes (1962) have shown that $40 \%$ of all the plaques of demyelination in chronic MS are located periventricularly. 
The extent to which Virchow-Robin spaces follow small vessels is not settled; if they penetrate to at least the arteriolar level, they could offer a potential communication between ECF and CSF in the subarachnoid space.

Controversy over the size of the CNS ECS continues according to KATZMAN (1968): is it 8,13 or $18 \%$ of the weight of the brain? The critical point is that there is an adequate amount of ECS for the free diffusion of compounds. The relatively low inulin ECS found in dead animals by RALL et al. (1962), approximately $4-6 \%$, is very reminiscent of the ECS estimated from electron micrographs. This suggests that at death cells within the CNS can swell and imbibe ECF. On the other hand, in plaques of demyelination due to MS obtained at postmortem, PÉrIER AND GRÉGOIRE (1965) have presented electron micrographs which show an enlargement of the ECS when compared to the surrounding normal-appearing white matter. The important point relative to MS is that the free movement of solutes between the CNS and CSF at least from the periventricular plaques of demyelination or those on the surface of the brain stem or spinal cord is not likely to be limited by the size of the ECS.

Many of the plaques of MS are deep in the white matter. Are these plaques accessible to the sink action of the CSF? Physical relationship of the CNS to the ventricles and subarachnoid space according to OLDENDORF (1967) reveals that there is no point which is more than $2 \mathrm{~cm}$ from the ependyma or pia. Most regions are within $1 \mathrm{~cm}$ and the parts of the CNS most likely to have plaques (periventricular surface, surface of the brain stem and spinal cord) are within a few $\mathrm{mm}$. This arrangement of CSF access to areas of demyelination may be a factor in the high incidence of the CSF IgG value indicative of MS in patients who have a minimum degree of demyelination.

On the other hand, all neurological physicians know that lumbar CSF can be normal in patients who eventually turn out to have MS. A complete answer to this enigma cannot be given; it will have to wait until we know more about the disease and its relationship to the CSF. Perhaps the size of the lesion and/or the distance from the CSF space could be a factor. Moreover, with $500 \mathrm{ml}$ of CSF formed per day an abnormality could be diluted out.

The activity of the lesion must be a factor. It is possible that a modestly active lesion produces too little of a substance to be detected in the fluid, e.g., lipids, lactic acid, enzymes, and immunoglobulin-G (IgG); or a lesion produces too small a change in the blood-CNS-CSF barrier so that the albumin and other serum proteins or constituents do not increase in the CSF. It is possible that anabolic or catabolic products of the demyelinating lesions are metabolized by reactive cells. These cells may find their way to the perivascular spaces for removal via the blood more readily than via the fluid space.

It goes without saying, based on the sink action theory of the CSF, that the discovery of the cause of MS will focus our attention on a search for it in the CSF or a tell-tale sign of its presence in the fluid.

Finally, since the physiology of formation, circulation and absorption of CSF has not been studied adequately in MS patients we look forward to these data also. It is, however, reasonable to think that they will turn out normal, since the CSF pressure, Queckenstedt test, fall of CSF pressure with timed withdrawal of fluid as well as reformation of CSF after withdrawal are normal (unpublished data). Further 
the incidence and severity of post-lumbar-puncture headaches in MS patients does not differ from that in normal individuals (TOURTELLOTTE et al. 1964).

\section{ORIGIN OF CSF TOTAL PROTEIN}

It is generally accepted that most if not all CSF proteins in health originate from the serum except the trace proteins and some of the $\beta$-globulins; they pass through a barrier which sets the protein content of CSF at approximately 1/200 that of the serum. The size of the molecule might be important since according to BURTIN (1964) all the proteins present in normal CSF have a molecular weight of no more than 160,000 . KabAT et al. (1942), Burtin (1960, 1964), McMenemey (1961), Laterre (1965) and LUMSDEN (1965a) have shown that alterations in the composition of the protein components of serum are reflected in the CSF. In particular MCMENEMEY (1961) found in myelomatosis that the serum protein elevations might relate to "typical" $\gamma$-globulin and to $\alpha_{2}$-globulin, but the principal increase may be in an abnormal $\beta$-globulin fraction occupying an intermediary position between $\beta$ and $\gamma$. In each of the instances where these fractions of the serum proteins were increased in myelomatosis, McMENEMEY found the same component disproportionately elevated in the CSF.

Recent observations by Frick (1960), ClaAusen et al. (1964), LATERre (1965) and CASPARY (1965) indicate that most if not all proteins based on immunoelectrophoretic characteristics in the serum and CSF are similar, which further supports the concept that the CSF protein is derived from serum.

There are only 2 protein fractions spotted on zone electrophoresis utilizing various supporting media (paper, cellulose acetate paper and agar gel) which stand out in normal CSF when compared to serum. They are pre-albumin and $\beta_{2}$-globulin ( $\tau$ fraction). The origin of pre-albumin is probably in the blood. LATERRE (1965) has used various methods on the CSF and serum (ultracentrifugation, immunoelectrophoresis, acrylamide and agar gel electrophoresis) as well as histo-immunofluorescence of the choroid plexus. They accumulated evidence that the pre-albumin in the serum was selectively concentrated by the choroid plexus in the process of secretion of CSF.

The question of the origin of the $\tau$-fraction may also be solved. LATERRE (1965) concluded from reports available in the literature as well as from his own personal studies that the $\tau$-fraction originates from serum transferrin; however, the serum transferrin has 4 more neuraminic acid groups than the CSF one. This alteration of the serum transferrin molecule changed the $R_{f}$ value on zone electrophoresis, but not its immunological characteristics. The removal of the 4 neuraminic acid groups from the serum transferrin molecules is the result of enzymatic hydrolysis by neuraminidase normally present in the nervous tissue; the hydrolysis is probably not the result of CSF neuraminidase.

The origin of CSF $\beta$-trace and $\gamma$-trace globulins is still controversial; they are spotted when an antiserum to CSF is used with immunoelectrophoresis and at one time they were said to be specific CSF proteins. According to LATERRE (1965) and LiNK (1967) these proteins with a molecular weight of $<30,000$, are not found in the serum. They are found in extracts of CNS and urine but probably not in extracts of the kidney. 
Supposedly because of their low molecular weight they diffuse easily throughout the body fluids from various tissue cells, such as from the CNS to the CSF.

On the other hand, in MS and in several other diseases there is evidence which has been accumulated (TourTellotTE AND PARKER 1968b) which suggests that the CNS is converted into an immunological organ capable of synthesizing IgG and antibodies. By diffusion through the ECF of the CNS from multifocal areas of synthesis, an elevated IgG in the CSF may reflect this newly-formed CNS protein. This thesis will be discussed in detail under a following section.

CLAUSEN et al. (1964) revealed that immunoelectrophoretic investigation of the CSF utilizing antisera against normal serum can be used as a diagnostic tool. Normal CSF contains only serum proteins with a molecular weight less than 160,000 . If a partial breakdown of the blood-CNS-CSF barrier occurs, this causes high molecular weight serum proteins to pass into the CSF compartment, for example, fibrinogen, $x_{2}$-macroglobulin and IgM.

The sites and rates of exchange of only 3 proteins, namely, albumin, IgG and $\beta$ globulin between CSF, blood and CNS have been studied in health and disease in both animals and man. According to LUMSDEN (1965a) these 3 proteins account for most of the CSF protein in health or disease making up in normal CSF on the average $88 \%, 58 \%$ for albumin, $20 \%$ for $\beta$-globulin and $10 \%$ for IgG. There is little question that in health both albumin and $\mathrm{IgG}$ are derived from the serum. The data to support this conclusion will be presented under following sections.

Frick AND SCHEID-SeYdel (1960) studied intravenously-injected labeled serum $\beta$-globulins in 20 patients with different diseases. When the dynamic equilibrium between serum and CSF was established, it was found that the CSF specific activity was always less than in the serum. They interpreted these results to support the hypothesis that some of the CSF $\beta$-globulin is derived from the serum, but because an equilibrium of unity was not established it was necessary to postulate a non-labeled pool; presumably the CNS was contributing to the CSF $\beta$-globulin. This hypothesis accords with the finding that the CSF normally contains a higher percentage of $\beta$-globulin than that in serum and that CSF $\beta$-globulin is partly made up of $\beta_{2-}$ or $\tau$-fraction, a neuraminic acid-deficient serum transferrin, not found in the serum. The passage of labeled $\beta$-globulin was no different in 3 MS patients than in the other cases studied.

On the other hand, an increase of the CSF proteins in disease might reflect not only degrees of change in the permeability of the blood-CNS-CSF barrier to serum protein, but also the local derivation of preformed or of newly-formed protein in the CNS. The degree of the change in the permeability of the blood-CNS-CSF barrier can be estimated by detecting an elevation of albumin in the CSF when the serum albumin level is not elevated and the flow of CSF is not blocked; hence, it can be a type of brain-CNS-CSF barrier test (see next section). On the other hand, the accumulation of excess IgG in the CSF can be the result of either a break of the barrier or the result of newly-formed protein in the CNS. Our group (TourTellotTE AND PARKER 1965, 1966a,b, 1967a, 1968a,b; TOURTELLOTTE et al. 1966, 1967, 1968) has presented data to support the hypothesis that there exists in the CNS of MS patients multifocal areas (the cell-type synthesizing IgG has not been identified) of synthesis of $\operatorname{IgG}$ with resulting diffusion of the IgG into the CSF. Further, pre-formed proteins, such as 
enzymes or lipoproteins which might be derived from diseased CNS cells possibly exist in MS CSF ; but at most they contribute only trivial amounts to the total protein concentration.

Data on the sites and rates of exchange of CSF proteins other than albumin, IgG and $\beta$-globulin found in the CSF are not known; probably their concentration is set by rules which govern the blood-CNS-CSF barrier. On the other hand, according to DENCKER et al. (1961) a macromolecule such as fibrinogen, a non-CNS protein, when it appears in the CSF, certainly reflects a more extreme damage to the blood-CNS-CSF barrier than just an elevation of albumin which is a smaller molecule than fibrinogen.

In summary then, from the standpoint of recent advances in the mechanisms which govern the concentration of CSF total protein in disease, it can be seen that we are not really interested in CSF total protein per se, but in the various types of proteins which make up the total protein. Based on a multitude of reports in the literature and our own experience, it has become obvious that our focus of attention for the understanding of the relationship of CSF to MS CNS lesions should be directed to the various proteins which constitute the total protein, especially albumin and IgG. Albumin concentration indicates the state of health of the blood-CNS-CSF barrier and an increase of IgG can do the same or reflect the existence of synthesis of IgG in the CNS.

This section on the origin of CSF total protein is important because the total protein can reflect the state of health of the blood-CNS-CSF barrier. Further, a study of CSF total protein is also of importance since total protein serves as the basis for the most popular quotient, $\gamma$-globulin as a percentage of total protein, which appears to reflect $\gamma$-globulin synthesis in the CNS even when the blood-CNS-CSF barrier is damaged.

\section{ORIGIN OF CSF ALBUMIN}

FishMAN (1953), utilizing radio-active-labeled albumin, showed in dogs that there exists a dynamic equilibrium between blood and CSF albumin. FrICK AND SCHEIDSEYDEL (1958a) reported on the exchange of [131I]albumin between blood and CSF in man. A steady equilibrium of unity was obtained in $60 \mathrm{~h}$ in normal individuals as well as in patients with various diseases (meningoencephalitis, neurosyphilis, CNS tumors and MS). The fact that a steady equilibrium of unity was obtained in health with any of a large spectrum of CNS diseases, some of which had extensive damage to the blood-CNS-CSF barrier, e.g. tuberculous meningitis, proved that albumin originated exclusively from the blood. Moreover, their data supported the idea that the CSF albumin was removed from the CSF space via the blood.

CUTLER et al. (1967a) also studied the origin of CSF albumin in man by following exchange of intravenously-injected ${ }^{125}$ I-labeled albumin between the blood and lumbar CSF in 17 patients. Patients with both normal and elevated CSF concentrations of total protein and albumin were included in the study. The relationship between blood and CSF specific activity indicated that CSF albumin was derived entirely from the blood albumin in all cases studied; the range of CSF albumin concentration was from 10 to $1800 \mathrm{mg} / 100 \mathrm{ml}$. The efflux coefficient denoting the fractional daily removal of CSF albumin was found to remain constant over this wide range of CSF albumin 
concentrations. On the other hand, the daily flux of albumin between plasma and CSF was found to vary directly with CSF albumin. Their data indicated that increased vascular permeability to albumin, rather than delayed removal from the CSF, was implicated in the pathogenesis of elevated CSF protein in their cases. The lack of dependency of the efflux coefficient upon CSF albumin concentration suggested that albumin was removed from the CSF compartment by a passive process that was not saturated by excess substrate. It was proposed that removal was accompanied by bulk flow through the arachnoid villi.

CUTLER et al. (1970) also estimated the rate of flux of albumin into the entire CSF compartment during the ventriculolumbar perfusion of humans. The albumin influx was comparable in the control patients as well as in those with elevated IgG values $(0.086-0.1 \mathrm{mg} / \mathrm{min})$.

To further support the hypothesis that CSF albumin is exclusively derived from the blood, let us turn to an elegant animal experiment. HocHWALD AND WALLENSTEIN (1967a) studied the exchange of [131I]albumin between blood, CSF and CNS in the cat. When the $\left[{ }^{131} I\right]$ albumin was given intravenously a steady-state of unity was accomplished between 4 and $20 \mathrm{~h}$ after injection. Because a steady-state value of unity was obtained in the CSF compared to the serum, this proved that all the CSF albumin arises from the blood. The reduction of CSF formation by acetazolamide (Diamox ${ }^{\circledR}$ ), a drug which has been shown to decrease the secretion of CSF at the choroid plexus, resulted in a decrease of albumin influx into the CSF. This result suggested that transfer of albumin from blood to CSF is only partially dependent (perhaps $40 \%$ ) on bulk fluid formation. Presumably $60 \%$ of the CSF albumin enters from the surrounding CNS tissue.

When the isotope was perfused through the ventricles it was removed by bulk absorption; presumably through the one way valvular microtubules in the arachnoid villi. Less than $0.1 \%$ of the radioactivity could be recovered from the CNS.

Hochwald (1970) also studied the influx of albumin to the spinal fluid along the neuraxis in cats. A difference of protein concentration between CSF obtained from the cisterna magna $(27 \mathrm{mg} / 100 \mathrm{ml})$ and spinal subarachnoid space fluid $(44 \mathrm{mg} / 100$ $\mathrm{ml}$ ) was found in the cat, a gradient reminiscent of that which exists in man. His results indicated that the differences in CSF protein concentration along the neuraxis was not due to an increase of protein permeability into the spinal subarachnoid space. He stated that a reasonable explanation for the increased protein concentration in the spinal subarachnoid space was based on regional differences of CSF circulation (slower); it is due to the constant protein influx from the spinal cord in the absence of CSF circulation which dilutes the protein which influxes from the CNS and transports it to the arachnoid villi for injection into the blood.

Therefore, based on the above reports there is little doubt that CSF albumin is exclusively derived from the blood and is returned to it in both health and disease.

It can be deduced from the studies presented above that the reasons for an increased CSF albumin are: (I) hemorrhage into the CSF space; (2) persistent elevated serum value since the CSF albumin equilibrates with it; (3) a lesion in the choroid plexus, since its secretion contains albumin; (4) damage of the blood-CNS barrier resulting in an increase of albumin in the CNS tissue which sets up a diffusion gradient so that 
the excess albumin (and other serum proteins) sink into the CSF; and (5) blockage of the flow of CSF, particularly in the spinal subarachnoid space, which permits albumin which normally diffuses from the CNS tissue to accumulate because it is not washed away by the normal flow of CSF.

In MS, a non-hemorrhagic disease (TOURTELlotTE AND PARKER 1968b), the serum albumin concentration is normal (TOURTELLOTTE AND PARKER 1967). In MS there are no data to show, and there is no reason to believe, that the secretory mechanism of the choroid plexus is abnormal. Moreover, if there were blockage of the flow of CSF in the spinal subarachnoid space this would be evidence against a diagnosis of uncomplicated MS. Therefore, until proven otherwise, an increase of CSF albumin in MS is likely to be the result of a damaged blood-CNS barrier.

TourtellotTe AND PARKer $(1967,1968 \mathrm{a}, \mathrm{b})$ have proposed that the concentration of albumin in the CNS corrected for intravascular albumin is a type of evaluation of the blood-CNS barrier in MS, a non-hemorrhagic condition (TOURTELLoTTE AND PARKER 1968b). We proposed this endogenous test of the blood-CNS barrier primarily because of the above-mentioned isotope reports, but also because albumin is a nonCNS protein synthesized only in the liver; hence, there is no chance that the CNS could synthesize albumin and contribute it to the CNS extracellular and CSF space. Further, it is well known that the concentration of serum albumin is a constant. For example, from our most recent data utilizing the immunochemical procedure of KABAT et al. (1948), 64 normal medical students had an average serum value of $4.64 \mathrm{~g} / 100 \mathrm{ml}$ (S.D. 0.458 and S.E.M. 0.058); whereas, in 54 MS patients the average value was 4.55 (S.D. 0.660 and S.E.M. 0.09). Hence, the MS serum albumin is precisely regulated and determined with the same precision as in normal individuals. As a result, the CNS is constantly perfused by an albumin solution (blood) of known concentration, another factor of importance in establishing a steady state ratio between CSF and serum albumin. The ratio of the CSF to serum albumin turns out to be on the average 1:230 in normal individuals. Also it is necessary that the test substance of the blood-CNS barrier is not readily catabolized by the CNS. We have shown that human serum albumin added to homogenates of CNS is quantitatively recovered (Tourtellotte And Parker 1966b). Moreover, incubation of CNS tissue up to $36 \mathrm{~h}$ postmortem revealed no change in the initial albumin concentration (unpublished data). Incidentally, similar results were obtained with IgG. Finally, the quantification of albumin with an antibody reagent is sensitive and specific (KABAT et al. 1948).

Therefore, the determination of CSF albumin in an uncomplicated case of MS is a test of the blood-CNS-CSF barrier.

It is possible to calculate the CSF albumin concentration based on data available in the literature obtained by various types of electrophoresis; however, the percentage of the total protein which is albumin as well as the total protein has to be given. It is not possible to deduce whether there is an elevation of albumin concentration in the CSF by inspection of the percentage distribution alone. For example, CSF specimens $\mathrm{A}$ and $\mathrm{B}$ could each have $50 \%$ of the total protein as albumin, both normal values. But if CSF specimen A contained $80 \mathrm{mg}$ of total protein $/ 100 \mathrm{ml}$ and specimen B, $40 \mathrm{mg}$, the concentration of albumin would be 40 and $20 \mathrm{mg} / 100 \mathrm{ml}$, respectively. Specimen $A$ is abnormal and $B$ is normal. 
In order to answer the question whether the blood-CNS-CSF barrier is abnormal in MS and how frequently, we will use data presented by KABAT et al. (1950) and data obtained at the University of Michigan Medical Center; both groups used the immunochemical method of KABAT et al. (1948). On the other hand, LumSDEN (1965a) and LATERRE (1965) have surveyed the literature and composed tables to which the reader can refer, if it is desired to make a more thorough report by including the data obtained by various electrophoretic methods.

According to KABAT et al. (1948) the normal average CSF albumin concentration $(\mathrm{mg} / 100 \mathrm{ml}$ ) was 18.5 (S.D. 5.7). The upper limit of normal was 29.9 (average +2 S.D.). Our average value on 67 normal medical student volunteers (21-30 years old) was $20.0 \mathrm{mg} / 100 \mathrm{ml}$ (S.D. 7.3 and S.E.M. 0.89). Our upper limit of normal was 34.5 (average +2 S.D.). The data on males and females were combined since there was no statistical difference in the means (TourtellotTE 1970).

KABAT et al. (1950) found in 100 cases of MS that 1 case out of 78 with a normal total protein concentration, $\leqq 55 \mathrm{mg} / 100 \mathrm{ml}(\mathrm{M}+2 \mathrm{~S} . \mathrm{D} ., P=0.05)$ had a significantly elevated albumin concentration (TourTELLOTTE 1970). However, when there was a significant elevation of the CSF total protein ( $>55 \mathrm{mg} / 100 \mathrm{ml}$ ), 19 out of 22 or $86 \%$ of the cases had a significant elevation of the albumin concentration. The 3 cases which did not have an elevated albumin had $<65 \mathrm{mg} / 100 \mathrm{ml}$ of total protein but $>55 \mathrm{mg} / 100 \mathrm{ml}$.

Our group (TourtellotTe 1970) has confirmed the results of KABAT et al. (1950). We found in 67 consecutive cases of MS that of 54 patients who had $<55 \mathrm{mg} / 100 \mathrm{ml}$ of total protein, none had a significantly elevated albumin concentration. However, in the 16 cases which had a significant elevation of the CSF total protein ( $>55 \mathrm{mg} / 100 \mathrm{ml}$ ) 14 out of 16 or $88 \%$ of the cases had a significant elevation of the albumin concentration. The 2 cases which did not have an elevated albumin had $<60 \mathrm{mg} / 100 \mathrm{ml}$ of total protein, but $>55 \mathrm{mg} / 100 \mathrm{ml}$.

Since our data and those of KАBAT et al. 1948, 1950) are so similar we have combined them in a plot (Fig. 1). It shows a positive correlation between the albumin and total protein concentration. The correlation coefficient $(r)$ was very high for the 4 sets of data as well as overall. $R$ values were $0.91,0.92,0.90,0.89$, and 0.88 for KaBAT's normal data, TourTellotTE's normal data, KABAT's MS data, TOUR TELLOTTE's MS data and overall, respectively.

If the degree of elevation of CSF total protein is a reflection of the extent of the damage to the blood-CNS-CSF barrier, it is our impression that the damage to the barrier is rarely extensive in MS. In our analysis of the CSF total protein (TourtellotTe 1970) we found that $77 \%$ of patients diagnosed as cases of MS on clinical grounds had a normal total protein and that $99 \%$ of the group had a total protein value $\leqq 108 \mathrm{mg} / 100 \mathrm{ml}$. Moreover, an acute worsening of the clinical condition less than 8 weeks prior to the CSF examination produced no further changes in the total protein and hence presumably no detectable change in the blood-CNS-CSF barrier.

Experience has taught us that when the CSF total protein is more than $108 \mathrm{mg} / 100$ $\mathrm{ml}$ we should be on the look-out for another diagnosis. In the light of the relationship of the CSF total protein to the blood-CNS-CSF barrier, it is reasonable to state that 


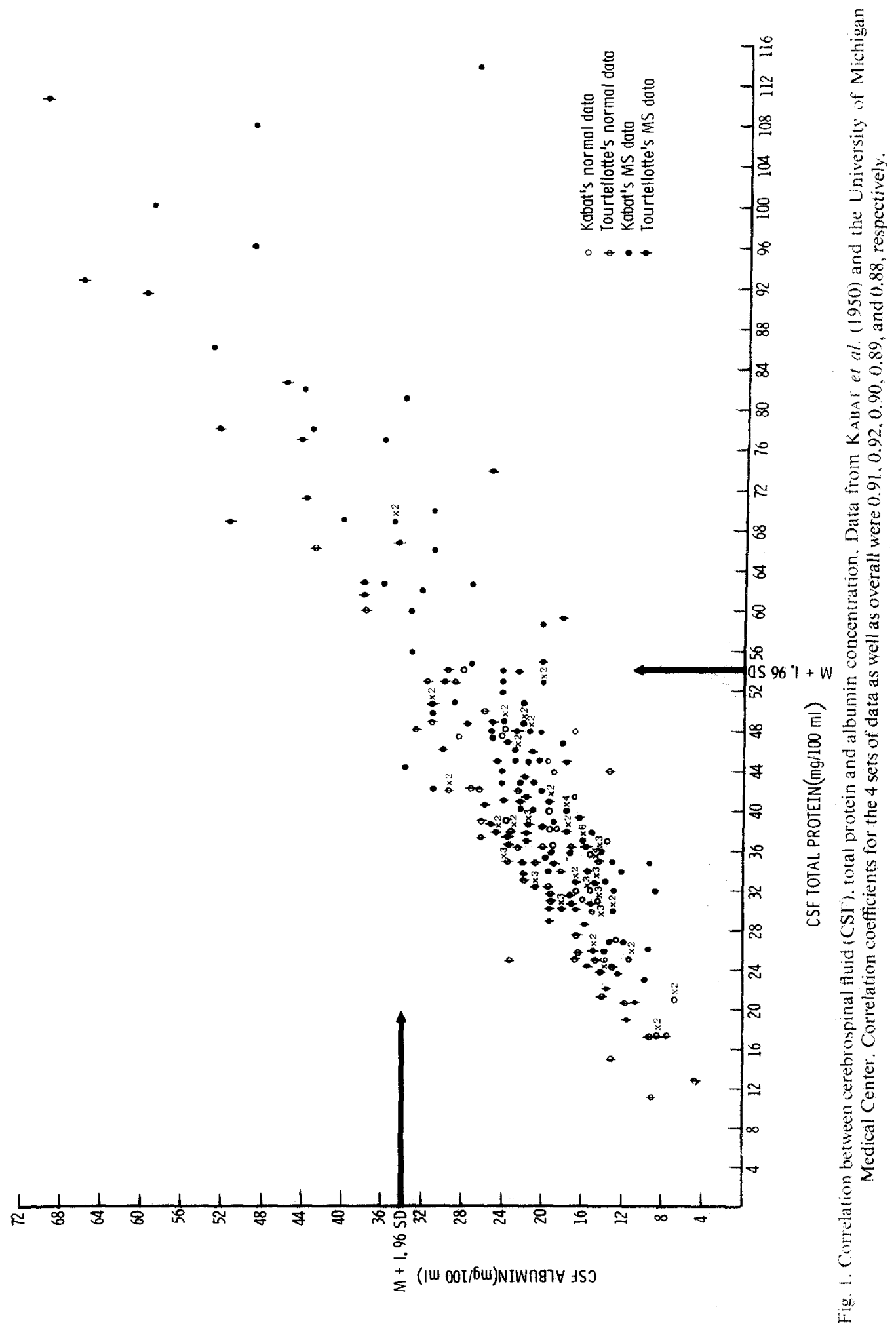


an extreme decrease of the barrier is unusual in an uncomplicated case of MS; this declaration has also been proposed by LATERRE (1965).

In summary, a significantly elevated CSF albumin concentration in MS is due to a decrease of the blood-CNS-CSF barrier. Based on this albumin test, about $20 \%$ of MS patients have an abnormal barrier. When the albumin concentration in the CSF was abnormal, so was the total protein. In all cases when the total protein was $>65 \mathrm{mg} / 100 \mathrm{ml}$, the albumin was significantly elevated. It is reasonable to conclude from the high degree of correlation between the albumin and total protein concentration of CSF (Fig. 1) that a significantly elevated total protein in MS reflects a decrease in the blood-CNS-CSF barrier. Accordingly, a CSF total protein determination is a convenient method for evaluation of the MS blood-CNS-CSF barrier. In the light of the extensive experience of other investigators (TOURTELLOTTE 1970) and of our own group with total protein concentrations in MS CSF we can conclude that a modest decrease in the barrier is found in approximately $23 \%$ of MS patients $(P=0.05)$ and an extreme decrease of the barrier is unusual $(P=0.003)$.

\section{ORIGIN OF CSF AND CNS IMMUNOGLOBULIN-G(IgG)}

Kabat et al. (1942), Lowenthal (1964), Burtin (1964), Wieme (1965), Laterre (1965), LUMSDEN (1965a) and DAVSON (1967) have included discussions of the origin of CSF immunoglobulins in health and various diseases. The following remarks give the historical perspective. Observations based on correlations of zonal electrophoretic patterns (Tiselius' free electrophoresis and supporting media of paper and various gels) as well as immunoelectrophoretic bands obtained on CSF and serum proteins leave no doubt that changes in the composition of serum $\gamma$-globulins strongly influences the CSF $\gamma$-globulins. Further, these correlation studies leave only some doubt that the CSF $\gamma$-globulin under normal conditions is derived from the blood; in health the average serum: CSF IgG ratio is 1:300. On the other hand, in diseases such as neurosyphilis, MS, subacute sclerosing panencephalitis (SSPE) and several others, the data suggest that not all of the CSF $\gamma$-globulin is derived from the blood. In these situations on the average the albumin: $\gamma$-globulin ratio of the CSF is significantly lower than that of the blood and the percentage of $\gamma$-globulin of the total protein was much higher than that in the serum. These data would suggest that some formation of $\gamma$-globulin could take place within the tissues of the CNS and then the newly formed $\gamma$-globulin could diffuse into the CSF, since it is difficult to imagine an altered permeability of the blood-CNS barrier which could produce an increase in $\gamma$-globulin without producing the same or an even greater increase in the smaller albumin molecule.

These speculations that $\gamma$-globulin can be synthesized in the CNS have been put on sounder experimental grounds by utilizing radioactive-labeled albumin and IgG to trace the exchange between blood, CSF and CNS.

The data presented by FRICK AND SCHEID-SEYdel (1958b), are most important in regard to the origin of CSF IgG. ${ }^{131} \mathrm{I}$-labeled IgG was injected intravenously into a variety of patients. In those patients whose blood-CNS barrier was judged as normal, and who had a normal CSF IgG value, they found that the IgG penetrated into the 
CSF more slowly than albumin; a steady state equilibrium of unity was established between the serum and CSF in 100 hours. Further, all the CSF IgG was derived exclusively from the serum. Moreover, in those cases where there was an acute change in the blood-CNS-CSF barrier, e.g., acute meningitis, all the CSF IgG was derived from the serum. On the other hand, 5 cases of MS with normal CSF total protein, that is, a normal blood-CNS-CSF barrier (see foregoing section), had an elevated CSF IgG value. They found that $16-92 \%$ of the CSF IgG was derived from some other source than serum-they suggested that it was produced locally in the CNS or its coverings.

LiPPINCOTT et al. (1965) have studied the passage of labeled IgG from the blood to the CSF and in the reverse direction in $21 \mathrm{MS}$ patients. The average time a molecule of IgG spent in the CSF compartment was $17.3 \mathrm{~h}$; whereas, in the blood compartment it was $72.4 \mathrm{~h}$. Hence, the IgG in the CSF compartment was found to be replaced 4.2 times as fast as it was in the blood compartment. In terms of recent advances in human CSF physiology (CuTLER et al. 1968; DAvson 1967) this rapid turnover of CSF IgG was largely the result of drainage and corresponded to a renewal rate of $0.1 \%$ per min. The constant for penetration from the blood into the CSF was about $1 / 11$ of this. Moreover, they stated that their transfer rate studies indicated that the total amount of IgG present in the CSF could not be accounted for solely as a result of physical transfer from the blood; their data confirmed that of FRICK AND SCHEID-SEYDEL. (1958b).

CUTLER et al. (1970) also injected intravenously radioactive albumin and $\gamma$-globulin (IgG) into 3 cases of MS, all with elevated IgG values. The data confirmed the earlier findings of FRICK AND SCHEID-SeYdel $(1958 \mathrm{a}, \mathrm{b})$ as well as those of LipPINCOTT et $a$. (1965). An apparent extravascular source of between 32 and $64 \%$ of the CSF IgG in patients with MS, had to be postulated. On the other hand, the similarities of the albumin influx rates in all patients studied suggested that the serum was always the source of the CSF albumin. They concluded that in MS there was synthesis of $\operatorname{IgG}$ within the CNS and that a CNS pool of JgG contributed significantly to the CSF IgG of MS patients.

Since Brightman (1965) and Rall et al. (1962) have demonstrated diffusion of macromolecules between CNS and CSF, it would be anticipated that $\mathrm{IgG}$, in high concentrations in the CNS could diffuse into the CSF.

Experiments by CUTLER et al. (1967b) on patients with subacute sclerosing panencephalitis (SSPE), a disease which is characterized by an elevated CSF IgG value, are germane for the hypothesis that the CNS is capable of becoming a type of immunological tissue, i.e., capable of synthesizing IgG of which a fraction is antibody protein. In this study they attempted to define the origin of the excess IgG in CSF. They studied the exchange of IgG labeled with ${ }^{125}$ I between serum and CSF in 2 patients with SSPE and in 3 control patients with normal CSF IgG concentrations. In the control subjects, all the CSF IgG was derived from the serum; while in the 2 patients with SSPE only 13 and $32 \%$ respectively was derived from the serum, a result reminiscent of that found in MS patients who had an excess of IgG in their CSF. The remainder of the CSF IgG originated from an unlabeled source, presumably through de novo synthesis in the CNS. 
Moreover, the flux of albumin and IgG into the CSF was measured during the ventriculolumbar perfusion of 8 patients with SSPE and 5 patients with brain stem tumors (controls). Total protein, albumin and IgG flux rates into CSF were linearly related to the concentration of these proteins in the CSF. In the patients with tumors the following mean values were obtained: total protein, $213 \mathrm{mg} /$ day; albumin, 124 $\mathrm{mg} /$ day; and IgG, $27 \mathrm{mg} /$ day. Corresponding values in the patients with SSPE, all of whom had a marked elevation of CSF IgG value were: total protein, $363 \mathrm{mg} /$ day; albumin, $144 \mathrm{mg} /$ day; and $\mathrm{IgG}, 154 \mathrm{mg} /$ day. While albumin entry rates were similar in both groups, the rate of IgG was increased six-fold. These observations provide quantitative data on the rate of turnover of albumin and IgG in CSF, and further support the concept that in certain neurological diseases $\operatorname{IgG}$ may be synthesized by cells within the CNS.

To further support the hypothesis that the CSF IgG in health is exclusively derived from the blood, an elegant animal experiment by HochWALD AND WALLENSTEIN (1967b) should be included. They studied the exchange of ${ }^{131}$ [-labeled IgG between blood, CSF and brain in the cat. When radioactive IgG was administered intravenously a steady-state of unity was obtained between 4 and $24 \mathrm{~h}$. Because acetazolamide (Diamox ${ }^{\circledR}$ ), a known inhibitor of CSF formation at the choroid plexus level, reduced the bulk fluid formation as well as the IgG influx, it was concluded that the transfer of IgG from blood to CSF was only partially dependent on bulk fluid formation by the choroid plexus. It was estimated that approx. $40 \%$ of the CSF IgG in health derives from the choroid plexus. The rest of the CSF IgG probably enters from the surrounding CNS ECS which RALL et al. (1962) has shown to be in direct communication with the CSF. It is assumed that the origin of albumin and IgG in the ECS was from the blood across the very effective blood-CNS barrier; only $0.1 \%$ of the labeled IgG could be recovered from the CNS when equilibrium was reached. In the cat approx. 0.79 and $0.42 \mu \mathrm{g} / \mathrm{min}$ influx from the CNS to the CSF for albumin and IgG, respectively. During steady-state ventriculocisternal profusion, the labeled IgG was cleared exclusively by bulk absorption of CSF; it was independent of protein concentration from $0.3 \mathrm{mg}$ to $500 \mathrm{mg} / 100 \mathrm{ml}$. Under normal conditions these data on IgG are very similar to those that HochwaLd AND WALLENSTEIN (1967a) found for albumin (see preceding section) except that the 24-h turnover for IgG was slower, approx. one-half that for albumin; presumably the larger IgG molecule, of 156,000 molecular weight, when compared to albumin, 40,000 , is a factor in the slower turnover rate.

These dynamic studies of Frick AND SCHEID-SEYdel, LiPPInCOTt et al., CUTLER et al. and HoCHWALD AND WALLENSTESN on CSF IgG utilizing radioactive tracers, taking into account their other data on albumin turnover, provide most impressive evidence supporting the hypothesis that the CNS in certain diseases, such as MS and SSPE, is capable of synthesizing a non-cerebral protein, namely IgG, which it does not do under normal circumstances.

The question of selective transport or secretion of $\mathrm{IgG}$ from the serum to the CSF has been suggested as a mechanism to explain the elevated IgG in MS CSF (CASPARY 1965). It is possible that a highly-selective filtration through the blood-CNS-CSF barrier tending to favor, for example, molecules of a certain size, shape and/or charge could allow an increase in the concentration of certain proteins in the CSF. It seems 
to me that this possibility of selective transport of IgG across the blood-CNS-CSF barrier has been eliminated by the isotope studies of FRICK AND SCHEID-SEYDEL. (1958b), LipPincotT et al. (1965) and CuTLER et al. (1967b, 1970). In control subjects and in those with a marked change in the barrier, e.g., acute meningitis, the equivalence of serum and CSF IgG specific activity at a time when CSF specific activity was maximal satisfied the criteria of a precursor-product relationship (CUTLER et al. 1967b). Thus serum IgG was the immediate source of CSF IgG in these patients. By contrast, in patients with SSPE as well as in MS patients, the markedly-lower CSF specific activity at equilibrium indicated that only a small portion of the total CSF IgG was derived from serum. It would be an expected result if a selective transport of IgG across the blood-CNS-CSF barrier were the only mechanism, that the serum and CSF IgG specific activity ratio should be greater than unity. By contrast, if the blood-CNS-CSF barrier were damaged, the ratio should be unity, but not higher or lower. On the other hand, it is always possible that there exists a combination of leakage, selective transport and synthesis de novo contributing IgG to the CSF IgG. Our interpretation of the CSF albumin data in MS patients (see section entitled ORIGIN OF CSF ALBUMIN) indicated that in approx. $20 \%$ of MS patients there is a modest decrease in the blood-CNS-CSF barrier. The fact is that in MS and SSPE at steady-state equilibrium of IgG (serum to CSF exchange) the ratio is less than unity; hence, a selective transport mechanism or damaged blood-CNS-CSF barrier cannot be the important mechanisms at work. Leakage and selective transport at most can only be contributing factors operating in the opposite direction to the more powerful CNS synthesis of IgG. To explain the data it is necessary to conclude that the most important fountainhead of MS CSF IgG is that an extravascular pool of IgG, presumably IgG synthesized in the CNS is contributing IgG to the CSF IgG on top of a normal contribution from the blood.

From the above reports we have been led to the conclusion that there exists in MS and SSPE an extravascular pool of IgG which is independent of the blood IgG but yet has ready access to the CSF. FrICK AND SCHEID-SEYDEL (1958b) suggested that the IgG originated from the CSF space which would include CSF cells, the covering membranes in contact with the CSF or the parenchyma of the CNS. KABAT et al. $(1948,1950)$ and CUTLER et al. $(1967 \mathrm{~b}, 1970)$ suggested it arose de novo in the CNS and diffused into the CSF. FIELD (1954) postulated that accummulation of lymphoid tissue in the CNS may be the source of the locally-produced IgG.

For some reason nobody had tested the CNS of MS and SSPE patients for increased IgG until 1964 when LoweNTHal (1964) made extracts of the CNS tissue and subjected them to agar gel electrophoresis. Gamma-globulins were usually detected in extracts made from CNS tissue with no obvious disease. On the other hand, extracts from MS or SSPE CNS tissue also obtained postmortem showed an excess of $\gamma$ globulins. He did not think that the increase of $\gamma$-globulin found was due to contamination by an excess amount of blood since the albumin concentration appeared to be within normal limits.

Tourtellotte and Parker (1965, 1966a,b, 1967 and 1968a,b) and Tourtellotte et al. $(1966,1967,1968)$ also at about this time made a systematic study of postmortem CNS tissue albumin and IgG in controls, as well as in cases of MS. The 
techniques used to determine the IgG in the $0.15 \mathrm{M}$ sodium chloride extracts were inspection of immunoelectropherograms, and the quantitative immunochemical technique of KАВAT et al. (1948). IgG was elevated 3 times on the average in 11 of $16(69 \%)$ postmortem MS brains (white matter and plaque) when compared to 10 controls. Hypergammaglobulinemia, hyperemia, change in the blood-CNS-CSF barrier checked by bromide and albumin, or binding of IgG to MS CNS tissue were not found to explain the elevated IgG in postmortem MS CNS. It was felt justifiable to conclude that most MS patients (probably active cases of MS) at the time of death have multifocal areas of synthesis of IgG in the CNS. Utilizing a direct fluorescent technique to detect the localization of IgG, Simpson et al. (1969) have shown that the fluorescence was most concentrated at the edge of active plaques. It is reasonable to propose that the plaque edge which shows histological evidence of active demyelination is a site for the synthesis of CNS IgG. The actual cells involved in the synthesis have not yet been identified. Could they be a type of glial cell, mononuclear leucocyte, plasma cell, macrophage or all of them? Other evidence has been presented to show that the high level concentration of IgG in the normal-appearing MS white matter and CSF is due to diffusion of IgG from a region of higher concentration. TOURTELLOTTE AND PARKer (1966a) showed a positive correlation between the concentration of IgG in plaques of demyelination due to MS as well as in normal-appearing white matter and the concentration of this globulin in the CSF. The tentative conclusion drawn from the results was that, in patients with MS, the increase in IgG in the CSF is a reflection of an excess of this globulin in the CNS.

Because we (TourTellotTe et al. 1968) had such interesting results in 1 case of SSPE, a CNS disease due to rubeola, we published it. Since then we have studied 10 other cases and all but one showed similar results. One of the characteristic features of SSPE is a prominent elevation of CSF IgG value in the presence of a normal serum IgG. It seemed reasonable to conclude that the same mechanism was acting to explain the elevated CSF IgG in SSPE as it was in MS, i.e., an increase of CSF IgG in the presence of normal serum IgG is a reflection of an excess of this globulin in the brain.

The patient we reported was a classical case of SSPE. Moreover, laboratory examination of the cerebral biopsy we studied revealed a myxovirus identified by electron microscopy and with fluorescent antibody measles reagent. The brain IgG was shown to be elevated by 2 methods: (a) inspection of immunoelectropherograms and $(b)$ quantitative immunochemical determination of $\operatorname{IgG}$ (6.4 times increased) after correction for blood IgG. Utilizing albumin as a test agent to check the bloodCNS barrier, the increase of IgG was due in part to a decrease in the blood-CNS barrier. On the other hand, it was calculated that approximately $95 \%$ of the CNS IgG arose from a source other than blood, presumably due to local synthesis in the CNS tissue. The measles antibody titer of the CNS tissue extract was $1: 80$ and that of the serum was $1: 16,384$ (fluorescent measles antibody method). Based on the serum concentration in the CNS and the serum measles antibody titer, calculations revealed that the CNS antibody titer should have been at least 1:235. To explain the low observed CNS measles antibody titer we have postulated that the virus particles released from the CNS cells by homogenization neutralized the majority of the extracellular measles antibodies. 
In summary, it can be concluded that in MS and SSPE it can be shown by several different methods (comparison of serum and CSF IgG, exchange of radioactivelabeled IgG and albumin between serum and CSF as well as ventriculocisternal perfusion, fluorescent IgG and albumin tracing in the CNS, and immunoelectrophoresis and quantitative immunochemical determination of IgG and albumin in CNS extracts), that there exists overwhelming evidence to support the hypothesis that the CNS can perform as an immunological tissue, i.e., it can synthesize $\operatorname{lgG}$ in MS and SSPE and in SSPE it can synthesize antibodies to measles virus as well as nonspecific IgG.

On the other hand, there are still experimental data missing which are needed to prove beyond reasonable doubt that the CSF IgG value can reflect that the MS CNS is performing like an immunological tissue, i.e. that it is synthesizing antibodies. First, what are the cells in the CNS tissue which do it? Can MS CNS tissue synthesize IgG in vitro? In order to establish that at least some of the IgG is antibody protein, it will be necessary to discover and isolate the antigen, for example, the virus or derivative of white matter which provokes the synthesis.

In summary, the predominant characteristic of the CSF profile indicative of MS is an elevation of its IgG value. Most MS patients have too much of this globulin in their body. Furthermore, it is a very special elevation, since it is compartmentalized to the CSF space and CNS tissue and little or no increase occurs in the blood. The question has arisen as to where this increased IgG originates? Data indicate that the fountainhead of IgG in health is exclusively the blood; whereas, when it is elevated in the CNS, unless there is a decrease in the blood-CNS barrier, or possibly hypergammaglobulinemia, it is synthesized in multifocal regions in the CNS, probably at the edge of active plaques of demyelination. After diffusion through the ECS of the CNS, the IgG sinks into the CSF which is circulating in the CSF space at the rate of $500 \mathrm{ml} /$ day. Finally, the enriched fluid is injected into the blood via the microtubules in the arachnoid villi.

Since the same mechanism has been suggested to explain the elevation of CSF IgG value in SSPE it may be that whenever there is an elevation of the IgG value in the CSF there exists in the CNS synthesis of IgG. The difference from one disease to another when this tell-tale sign exists may be the antigen which triggers the CNS to produce IgG, some of which is antibody protein and the remainder non-specific IgG. Perhaps we should conclude that an elevated CSF IgG value (percentage of the total protein which is $\mathrm{IgG}$ ) is indicative of synthesis of IgG in the CNS: in practice, if neurosyphilis is excluded, it turns out that MS is by far the most frequent cause of the CSF profile indicative of synthesis of IgG in the CNS.

The question has arisen whether the CSF leucocytes in MS are capable of synthesizing enough IgG to have an effect. A recent study by COHEN AND BANNisTer (1967) included 1 patient with MS who had a lymphocyte count of $68 / \mathrm{mm}^{3}$. The cells harvested from this patient synthesized immunoglobulins-G and $-A$, but not $-M$. They suggested that their data provided a direct demonstration that immunoglobulins-G and -A present in the CSF, were derived at least in part from cells within the CNS. Unfortunately, no controls were reported in order to determine if CSF leucocytes obtained from normal individuals or patients with other diseases had this potential. 
COHEN AND BANNISTER inferred that the synthesis could be going on in the free floating CSF cells as well as in similar cells in the CNS.

SANDBERG-Wollheim et al. (1969) also studied synthesis in vitro of IgG by cells from the CSF in a patient with MS. They found evidence for synthesis of IgG during a relapse of the disease; however, IgG synthesis was just detectable when the CSF cells were obtained from the same patient in a remission. It was suggested that the CSF cells were antigenically stimulated when the patient was in a relapse, but not in remission.

Can the circulating lymphocytes in the CSF account for the concentration of CSF IgG in MS? First, we need some basic information. According to ForbeS AND HENDERSON (1966) human peripheral lymphocytes do synthesis IgG and the basal rate of secretion can be increased 2.4 times when stimulated with phytohemagglutinin which presumably provokes maximal stimulation of synthesis. HiRSCHHORN et al. (1963) calculated that 1 million lymphocytes stimulated by phytohemagglutinin produced $10 \mu \mathrm{g}$ of IgG in $24 \mathrm{~h}$.

In the average MS patient $20.8 \%$ of the CSF total protein $(48.5 \mathrm{mg} / 100 \mathrm{ml})$ is $\mathrm{IgG}$ (Tourtellotte 1970); thus there is $10 \mathrm{mg} \mathrm{IgG/100} \mathrm{ml} \mathrm{CSF}$. A fraction of this IgG originates from the blood. If we assume no change in the blood-CNS-CSF barrier in the average MS patient, it is equal to that amount found in normal CSF. Accordingly, in the average normal individual $9.9 \%$ of the CSF total protein $(36.4 \mathrm{mg} / 100 \mathrm{ml})$ is $\mathrm{IgG}$; i.e. there is $3.6 \mathrm{mg} \mathrm{IgG/100} \mathrm{ml} \mathrm{CSF}$. Hence, $6.4 \mathrm{mg} \mathrm{IgG/} / 100 \mathrm{ml}$ is the calculated IgG which has to be accounted for by synthesis inside the blood CNS-CSF barrier. If $500 \mathrm{ml}$ of CSF is formed per day then $32 \mathrm{mg}$ of $\mathrm{IgG}$ is synthesized per day by the average MS patient.

The average MS patient has 6 leucocytes $\mathrm{mm}^{3}$ of CSF of which $90 \%$ are lymphocytes (TourtellotTe 1970); hence, there are on average 5.4 lymphocytes $\mathrm{mm}^{3}$ or $5.4 \times 10^{5}$ lymphocytes $/ 100 \mathrm{ml}$ or $2.7 \times 10^{6}$ lymphocytes appearing in the circulating CSF per day. A million lymphocytes maximally stimulated can produce $10 \mu \mathrm{g}$ of IgG per day according to ForBes AND HENDERSON (1966). Hence $27 \mu \mathrm{g}$ could be synthesized by the lymphocytes which appear in the circulating CSF in a day or $<0.1 \%$ of the $32 \mathrm{mg}$ to be accounted for. On the other hand, if tissue lymphocytes are responsible for the extra-IgG in MS, 3.2 billion lymphocytes would be needed which is a reasonable number. In summary, it can be said based on current knowledge regarding the ability of lymphocytes to synthesize and secrete IgG, that by calculation, circulating MS CSF lymphocytes, even if maximally stimulated, could only account for $<0.1 \%$ of the extra-IgG in the CSF per day.It is reasonable to assume that at least a fraction of the "cerebrogenic" IgG arises from tissue lymphocytes. Perhaps it is synthesized and secreted into the ECS of the CNS by a calculated 3.2 billion lymphocytes per day and it then diffuses into the CSF.

\section{QUOTIENTS}

KАBAT et al. (1948) found that the absolute concentration of CSF IgG (mg/100 ml) varied with the amount of total protein. Under preceding sections it was judged that an elevation of the CSF albumin was a reflection of the damage to the blood-CNS-CSF 
barrier or blockage of flow of CSF in the spinal subarachnoid space. Further, there was a remarkable correlation between the elevation of CSF albumin and total protein. This being so, it would be expected that the higher the total protein the more extensive would be the transudation of the various serum proteins into the CSF, including IgG and in extreme conditions even macromolecules such as fibrinogen. It is of interest that KABAT et al. (1948), many years before a explanation of the mechanism was available, found that the absolute concentration of CSF IgG $(\mathrm{mg} / 100 \mathrm{ml}$ of CSF) varied with the amount of total protein, no matter which disease caused it. Further, they discovered when the results were expressed as a ratio of the total protein, there emerged a pattern which discriminated MS from most other diseases: i.e., MS CSF had a significantly increased ratio. The reporting of CSF results as the fraction of IgG to the total protein expressed as a percentage is logically justified in the light of recent advances in CSF physiology and some new aspects of the pathology of MS. The quotient will normalize the increase of CSF IgG due to abnormal transudation from the serum, since other proteins included in the total protein, e,g., albumin, will increase in a proportional amount, no matter how extensive the blood-CNS-CSF barrier damage. On the other hand, the quotient of IgG: total protein would signal an extravascular source of IgG, presumably IgG synthesis de novo in the CNS, if an increased quotient was found. CSF albumin: CSF IgG ratio is a similar type of quotient and logically should be more discriminative than $\mathrm{IgG}$ : total protein since the total protein includes the de novo synthesized IgG too. In fact we found that there really is not much difference: $73 \%$ of MS patients had an elevated quotient---practically identical to the incidence, $67 \%$,found when the quotient CSF IgG: CSF total protein was used (TOURTELLOTTE 1970).

Bergmann et al. (1964) and Cosgrove and Agius (1966) utilized paper electrophoresis to separate the CSF proteins; they found that $93 \%$ of patients with MS had a decreased $\beta$-globulin: $\gamma$-globulin ratio. According to DENCKER (1969) on the average the concentrations of $\beta$-globulin are not changed in MS. On the other hand, the $\gamma^{\prime}-$ globulin concentration in MS is frequently increased as may be the albumin value. So when the percentage distribution of the various protein fractions is calculated from the total densitometry reading, the $\% \gamma$-globulin fraction would be increased and the $\beta$-globulin would have to be decreased. Consequently, the ratio of these two percentages would reflect a larger change in $\gamma$-globulin, than would $\gamma$-globulin expressed as a percentage of the total protein. Even though this quotient, when compared to others, is based on an artifact of calculation, its sensitivity merits its inclusion in this review.

SCHINKO AND TSCHABITSCHER (1959) as well as BERGMANN et al. (1964) expressed the changes in $\gamma$-globulin in terms of the quotient, CSF $\gamma$-globulin: serum $\gamma$-globulin. They found that the quotient increased in MS. The increase in the ratio could be the result of $\gamma$-globulin synthesized in the CNS which had diffused into the CSF and/or a change in the blood-CNS-CSF barrier with transudation of serum $\gamma$-globulin into the CSF. Since this quotient does not separate out the transudation of $\gamma$-globulin into CSF across a damaged blood-CNS-CSF barrier, it is expected that this quotient would be abnormally increased in any patient with a damaged barrier; hence as they point out this decreases its usefulness in supporting the diagnosis of MS when the bloodCNS-CSF barrier is only slightly damaged as it is in $20 \%$ of MS patients. Moreover 
an elevation of CSF total protein is almost always combined with a diminished bloodCNS-CSF barrier function. The CSF protein pattern then becomes more like that of the serum, and the quotient loses its value as an index to distinguish between increased $\gamma$-globulin derived by synthesis and diffusion across a damaged blood-CNS barrier.

A FORMULA WHICH ESTIMATES THE AMOUNT OF IgG EXPRESSED IN mg, SYNTHESIZED PER DAY BY THE MS CNS

We have devised a calculation which yields the quantity of CSF IgG synthesized per day by the CNS. The principle of the method is that the excess albumin in the CSF, if it occurs, is a quantitative marker of a damaged blood-CNS-CSF barrier. It is assumed that for each $\mathrm{mg}$ of excess albumin that passes the damaged barrier from the blood, there is a proportional quantity of IgG which moves into the CSF. After determination of the excess CSF IgG and correcting for the amount that comes from the serum, we arrive at a value which, if it exceeds zero, reflects the synthesis of $\mathrm{IgG}$ in the CNS. Since $500 \mathrm{ml}$ of CSF are formed and absorbed each day in normal man, and there is no reason to believe that the quantity is more or less in MS patients, we can calculate the amount of IgG made by the CNS each day.

We shall first consider the application of the formula when the blood-CNS-CSF barrier is normal. A calculation to express the average amount of IgG synthesized by the CNS per day by an average MS patient is possible. Normally, $18.5 \mathrm{mg}$ of IgG per day come from the blood [normal CSF IgG concentration is $3.7 \mathrm{mg} / 100 \mathrm{ml}$ (TOURTELLOTTE 1970)] and $500 \mathrm{ml}$ of CSF are formed and absorbed per day according to CUTLER et al. (1968). There is no reason to believe that this rate of formation of $\mathrm{IgG}$ which normally leaks across the blood-CNS-CSF barrier does not continue in MS patients, even when there is a neurogenic origin of IgG. The average MS patient turns over $50 \mathrm{mg} \mathrm{IgG/day} \mathrm{[the} \mathrm{average} \mathrm{MS} \mathrm{CSF} \mathrm{IgG} \mathrm{concentration} \mathrm{is} 10.0 \mathrm{mg} / 100 \mathrm{ml}$ (TOURTELLOTTE 1970) and $500 \mathrm{ml}$ of CSF are formed and absorbed per day]. If there is no change in the blood-CNS-CSF barrier in the average MS patient (this is a reasonable assumption in view of the average MS total protein of $48.5 \mathrm{mg}$ per $100 \mathrm{ml}$ and the albumin of 25.2 , both within the normal limits), then the average MS patient's CSF IgG is made up of $37 \%(18.5 / 50)$ of IgG derived from the blood and $63 \%$ $(31.5 / 50)$ derived from synthesis de novo in the CNS. By direct measurement utilizing ventriculolumbar perfusion, CUTLER et al. (1967b) found in a more lethal condition, SSPE, 4 times the CNS synthetic rate that we have calculated for MS. However, we have had MS patients who by calculation have approached the rate they found in SSPE (Table 1).

We shall now consider the usage of the formula where there is an abnormal bloodCNS-CSF barrier, i.e. an excess of albumin. Since our data agree reasonably well with those of KABAT et al. (1950) and since they have published the results on each case (their Table 3) we tested our method of calculation on their data, and found that it worked equally as well as on our own data. For example, KABAT's Case 87 had a total protein value of $69 \mathrm{mg} / 100 \mathrm{ml}$. The albumin concentration was $35 \mathrm{mg} / 100$ $\mathrm{ml}$. The upper limit of normal albumin according to KABAT et al. is 30 , so there was $5 \mathrm{mg} / 100 \mathrm{ml}$ of excess albumin. The normal serum IgG: albumin ratio according to 


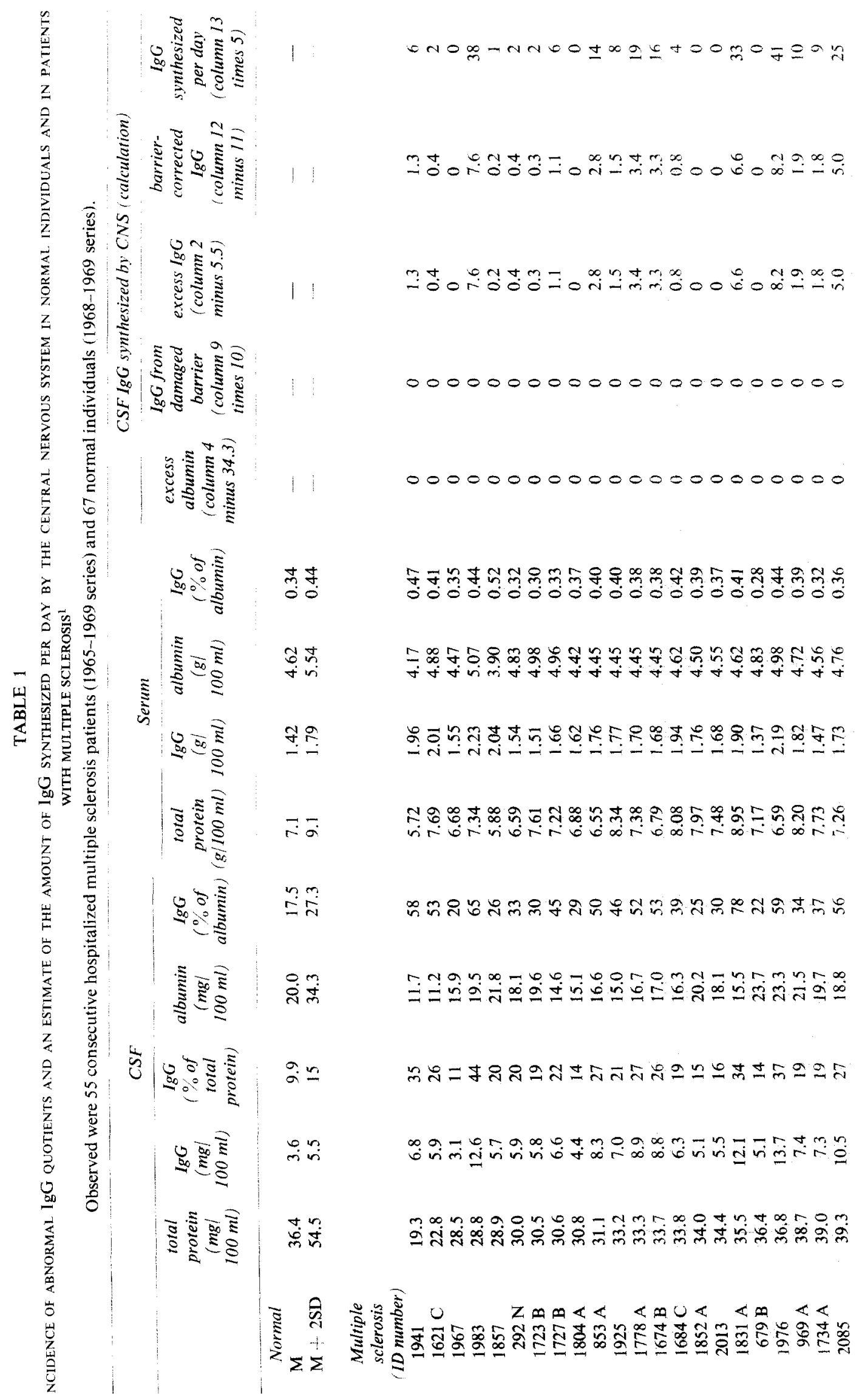




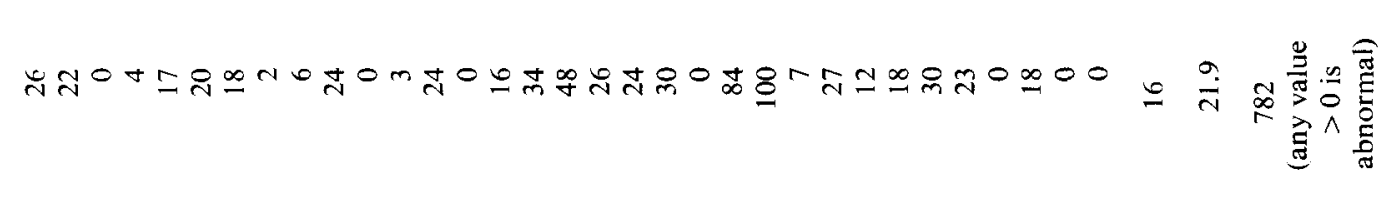

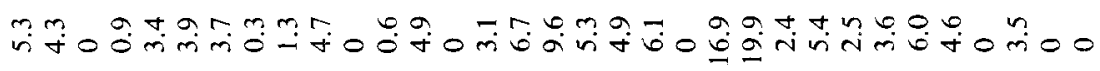

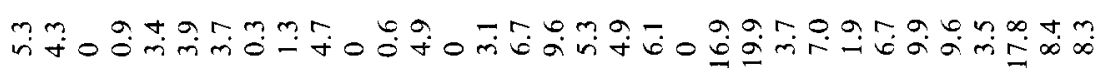

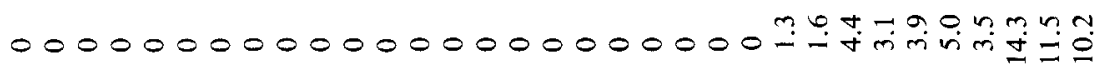

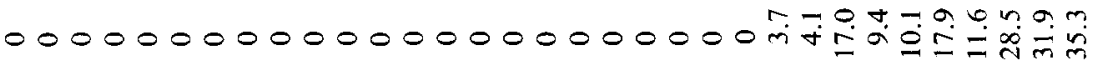

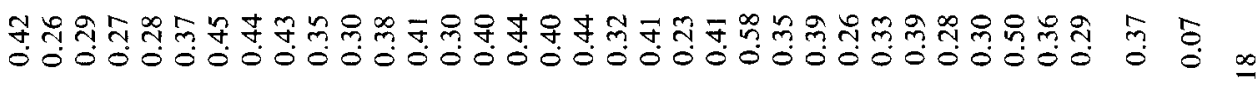

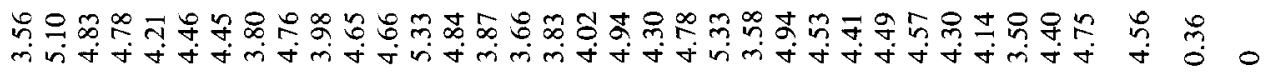

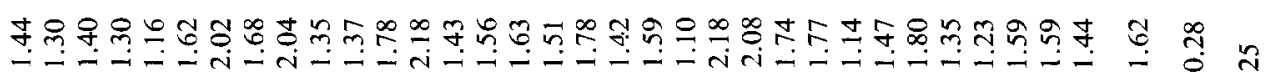

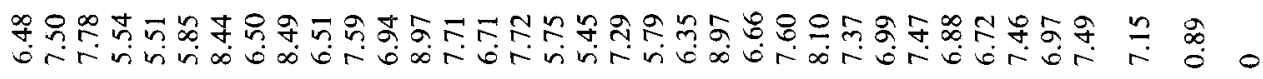

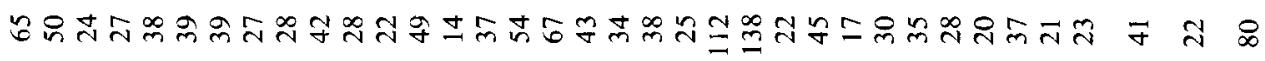

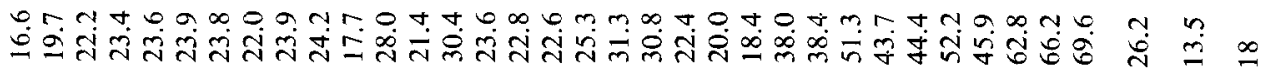

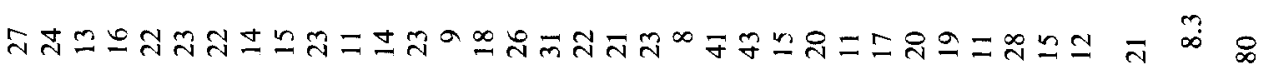

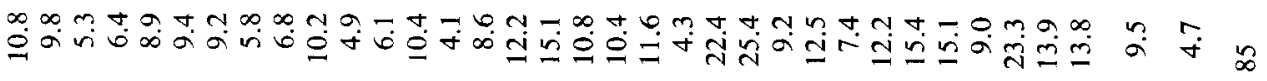

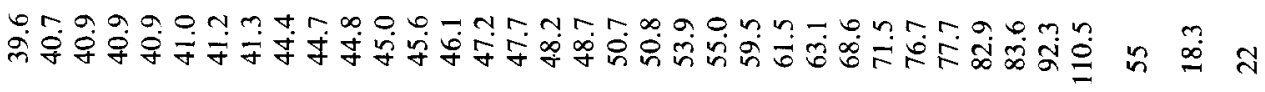

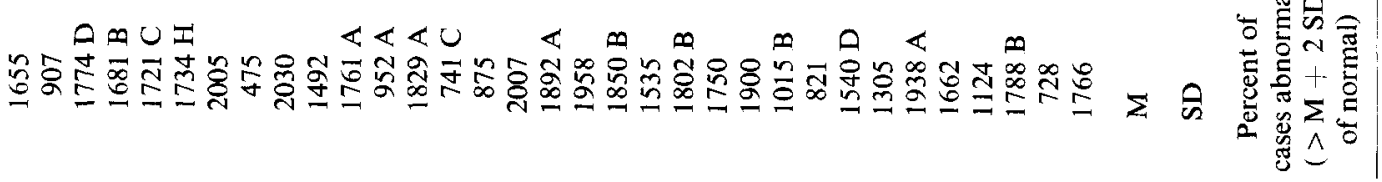


Tourtellotte and Parker (1965) is 0.35 . Accordingly, if $5 \mathrm{mg}$ of albumin per 100 $\mathrm{ml}$ passed from the serum to the CSF via the damaged blood-CNS-CSF barrier, then $1.7 \mathrm{mg} \mathrm{IgG} / 100 \mathrm{ml}$ were derived from the serum $(5 \times 0.35)$ and should be subtracted from the CSF IgG concentration. The CSF IgG in Case 87 was $21 \mathrm{mg} / 100 \mathrm{ml}$; subtraction of the upper limit of normal $\mathrm{IgG}, 6.5 \mathrm{mg} / 100 \mathrm{ml}$ and the amount derived from transudation across the damaged blood-CNS-CSF barrier, 1.7 , yields $12.8 \mathrm{mg}$ $\mathrm{IgG} / 100 \mathrm{ml}$ which is derived from some other source than the serum, presumably synthesized de novo in the CNS. Since $500 \mathrm{ml}$ of CSF is made per day, in Case 87 , $64 \mathrm{mg}$ of IgG was being made each day. This value is not unreasonable in the light of the data presented by CUTLER et al. (1967b). They found a value of $120 \mathrm{mg}$ per day synthesized by the CNS in cases of SSPE when a direct measurement was made during the course of ventriculolumbar perfusion.

In Case 87 it should be noted that the percentage IgG of total protein was also markedly abnormal, i.e. $30 \%$; their upper limit of normal was $13 \%(P=0.05)$. Further, we found $81 \%$ of the cases to be abnormal with our sophisticated calculation and the IgG expressed as a percentage of total protein was abnormal in $79 \%$ of the cases. The remarkable agreement between these two calculations should encourage the use of our formula to estimate the least amount of IgG, expressed in mg, synthesized per day by the MS CNS.

Further refinement and individualization of the formula is possible. If the CSF IgG and albumin, as well as the serum values are known, it is possible to calculate the serum IgG: albumin ratio for a given patient. As a result, the normal serum IgG: albumin ratio, which, according to Tour TEllotTe AND PARKER (1965) is 0.35, can be replaced in the formula for the one that the patient actually has. Therefore the effect of abnormally high or low serum albumin or IgG on the calculation of the excess CSF IgG which transudated from the serum into the CSF if a blood-CNS-CSF barrier existed could be more precisely adjusted.

In Table 1, we have presented data on 55 consecutive MS patients investigated so that the reader can try other types of analyses. The normal values obtained from college students aged 21-30 years are also presented. The average MS patient's CNS was found to be producing at least $16 \mathrm{mg} \mathrm{IgG} /$ day with a range of $0-100 \mathrm{mg}$. Our calculation by definition yields no synthesis in normal individuals since we have used mean +2 standard deviation cut-off limits. Hence a calculated value $>0$ is significant.

It should be noted that this series of MS patients presented in Table 1 is similar to our larger series reported by my group elsewhere (TOURTELLOTTE 1970). This sample showed a higher percentage of MS patients with elevated IgG value in the CSF, i.e., $80 \%$ compared to our other larger sample, $67 \%$ (TourTellotTE 1970 ) ; I believe this difference in incidence merely reflects a difference in sample size. The important point is that the percentage incidence of abnormal MS patients is the same for each of 2 quotients presented, namely, CSF IgG as a percentage of total protein and CSF $\mathrm{IgG}$ as a percentage of albumin, as well as the percentage incidence of MS patients who showed any synthesis of IgG per day.

Also of interest is that the least amount of IgG synthesized by an average MS patient per day in this series was $16 \mathrm{mg} /$ day with a range of $0-100 \mathrm{mg} /$ day. The total body 
pool of IgG is $66 \mathrm{~g}$ which turns over at the rate of $7 \%$ per day (JANEWAY et al. 1967). The maximum production by the MS CNS we found, $100 \mathrm{mg} / \mathrm{day}$, could only add to it by $2 \%$. Perhaps this is the explanation for the modest hypergammaglobulinemia found in some $(20 \%)$ of MS patients (Tourtellotte 1970). Perhaps the quality of the IgG synthesized by the MS CNS and returned to the blood is more important than the quantity; i.e., antibodies to specific antigen, such as virus or white matter derivatives.

\section{COMMENTS}

TOURTELlotTe (1970) has listed, based on clinical experience, the diseases which can produce an elevated CSF IgG value. In this report we have attempted to defend the hypothesis that an elevated CSF IgG value in MS is the result of a basic mechanism of the CNS which does not operate normally. IgG diffuses through the ECS of the CNS into the CSF from sites of synthesis of IgG in the CNS, but yet it is contained inside the blood-CNS-CSF barrier. It is possible for the synthetic mechanism to be operating very vigorously as it probably does in an active case of SSPE, or moderately as in active neurosyphilis, or modestly as it does in the average case of MS. It is possible that it stays "turned on" for a short time with self-limited viral infections such as poliomyelitis. It might continue to act as an immunological organ for prolonged periods with slow infections, such as SSPE, subacute necrotizing encephalitis, neurosyphilis, and trypanosomal encephalitis. Furthermore, a damaged blood-CNSCSF barrier could permit antibodies and leucocytes to enter the CNS more rapidly, but it would appear that this is an extreme reaction of short duration in MS, since the blood-CNS-CSF barrier is normal in $80 \%$ of the cases and only modestly abnormal in the rest. More than likely most of the IgG synthesized in the CNS is not antibody protein. It may be that the concentration of non-antibody IgG in the ECS of the brain is part of a regulatory mechanism to slow down the CNS synthesis of IgG protein so that it will not become malignant. It should be mentioned that this basic mechanism of the CNS to synthesize IgG is a defense mechanism, but it must be considered that endogenous antigens, such as derivatives of white matter might turn it on and hence it could destroy the CNS by autoclasia (LUMSDEN 1965b). For the autoimmune hypothesis to be realistic it would appear that the mechanism of removal of antigenic debris by lysosomal enzymatic hydrolysis, especially acid proteinases which readily hydrolyse basic protein of myelin, would have to be faulty in MS, which histopathologically does not appear to be the case.

In our pursuit of the pathogenesis of MS, it is my impression that we have come upon a basic mechanism of the CNS which operates in a number of diseases which are infrequent enough and which are easily differentiated on clinical grounds from $\mathrm{MS}$, so that the CSF IgG value becomes of some use in supporting the diagnosis of MS.

\section{ACKNOWLEDGEMENTS}

I wish to acknowledge with enthusiasm my entire staff for making this report possible; but especially Julius A. Parker, M. A., Research Associate in Neurology. 
This review of the cerebrospinal fluid (CSF) changes in multiple sclerosis has brought together relevant recent advances in CSF physiology and some aspects of the pathology of MS as they relate to the CSF IgG quotients.

A defense of the hypothesis that an elevated CSF IgG value in MS is the result of a basic mechanism of the CNS which does not operate normally, i.e., that IgG diffuses through the ECS of the CNS into the CSF from sites of synthesis of IgG in the CNS, but it is contained inside the blood-CNS-CSF barrier which is only accasionally slightly abnormal is presented. It is proposed that this basic mechanism underlies the elevated CSF IgG quotients (IgG/total protein and IgG/albumin): other diseases which induce the CNS to become an immunological organ, i.e., to produce IgG, are clinically infrequent and are easily differentiated on clinical grounds from MS; thus the elevated CSF IgG quotient found in over two-thirds of the cases of MS becomes of value in supporting the diagnosis of MS.

Finally, a formula is presented which estimates the amount of $\mathrm{IgG}$, expressed in $\mathrm{mg}$, which is synthesized per day by the MS CNS. The average amount synthesized per day by a MS patient is $16 \mathrm{mg}$ with a range of $0-100 \mathrm{mg}$.

\section{REFERENCES}

Bergmann, L., O. Gilland, S. Olanders and L. Svennerholm (1964) Clinical profile and paper electrophoresis in multiple sclerosis, Acta neurol. scand., 40, Suppl. 10:33-48.

BRIGHTMAN, M. W. (1965) The distribution within the brain of ferritin injected into cerebrospinal fluid compartments, Part 2 (Parenchymal distribution), Amer. J. Anat., 117: 193-220.

BrownELl, B. AND J. T. Hughes (1962) Distribution of plaques in the cerebrum in multiple sclerosis, J. Neurol. Neurosurg. Psychiat., 25: 315-320.

Burtin, P. (1960) Les protéines du liquide céphalorachidien. In: P. Grabar and P. Burtin (Eds.), Analyse Immuno-électrophorétique: Applications aux Liquides Biologiques Humains, Masson, Paris, p. 245.

Burtin, P. (1964) The proteins of the cerebrospinal fluid. In: P. Grabar and P. Burtin (Eds.), Immunoelectrophoretic Analysis, Elsevier, Amsterdam, pp. 244-251.

CASPARY, E. A. (1965) Comparison of immunological specificity of gamma globulin in the cerebrospinal fluid in normal and multiple sclerosis subjects, $J$. Neurol. Neurosurg. Psychiat, , 28: 61-64.

Clausen, J., J. MatzKe and W. Gerhardt (1964) Agar-gel micro-electrophoresis of proteins in the cerebrospinal fluid: normal and pathological findings, Acta neurol. scand., 40, Suppl. 10: 49-56.

COHEN, S. AND R. BANNISTER (1967) Immunoglobulin synthesis within the central nervous system in disseminated sclerosis, Lancet, i: 366-367.

Cosgrove, J. B. R. AND P. Agrus (1966) Studies in multiple sclerosis, Part 2 (Comparison of the $\beta \cdots ;$ globulin ratio, $\gamma$-globulin elevation, and first-zone colloidal gold curve in the cerebrospinal fluid), Neurology (Minneap.), 16:197-204.

Cutler, R. W. P., R. K. Deuel and C. F, Barlow (1967a) Albumin exchange between plasma and cerebrospinal fluid, Arch. Neurol. (Chic.), 17:261-270.

Cutler, R. W. P., G. V. Watters and J. P. Hammerstad (1970) The origin and turnover rates of cerebrospinal fluid albumin and $\gamma$-globulin in man, J. neurol. Sci., 10: 259-268.

Cutler, R. W. P., L. PAGe, J. Galicich and G. V. Watters (1968) Formation and absorption of cerebrospinal fluid in man, Brain, 91: 707-720.

Cutler, R. W. P., G. V. WATters, J. P. Hammerstad and E. Merlen (1967b) Origin of cerebrospinal fluid $\gamma$-globulin in subacute sclerosing leukoencephalitis, Arch. Neurol.(Chic.), 17:620-628.

Davson, H. (1967) Physiology of the Cerebrospinal Fluid, Little Brown, Boston, Mass.

Davson, H. AND M. B. SEGAL (1969) Effect of cerebrospinal fluid on volume of distribution of extracellular markers, Brain, 92:131-136.

DENCKER, S. J. (1969) Quantification of individual CSF proteins by immune precipitation in agar gel, J. Neurochem., 16:465-466. 
Dencker, S. J. ANd B. SWahn (1961) Clinical Value of Protein Analysis in Cerebrospinal Fluid, a Micro-Immunoelectrophoretic Study, Gleerup, Lund.

DenCKer, S. J., R. BRönNestam AND B. Swahn (1961) Demonstration of large blood proteins in cerebrospinal fluid, Neurology (Minneap.), $11: 441-444$.

FIELD, E. (1954) The production of $\gamma$-globulin in the central nervous system, $J$. Neurol. Neurosurg. Psychiat., 17: 228-232.

Fishman, R. A. (1953) Exchange of albumin between plasma and cerebrospinal fluid, Amer. $J$. Physiol., 175: 96-98.

Forbes, I. J. AND D. W. Henderson (1966) Globulin synthesis by human peripheral lymphocytes. In vitro measurements using lymphocytes from normals and patients with disease, Ann. intern. Med., 65: 69-79.

FRICK, E. (1960) Immunologische Untersuchungen zur Identifizierung einzelner Liquoreiweisskörper, Klin. Wschr., 22: 1135-1139.

Frick, E. AND L. SCheId-SEYdel (1960) Untersuchungen mit $\mathbf{J}^{131}$-markiertem Globulin zur Frage der Abstammung der Liquoreiweisskörper, Klin. Wschr., 38: 1240-1243.

FRICK, E. AND L. SCHEID-SEYDEL (1958a) Untersuchungen mit J131-markiertem Albumin über Austauschvorgänge zwischen Plasma und Liquor cerebrospinalis, Klin. Wschr., 36: 66-69.

FRICK, E. AND L. SChEID-SEYdel (1958b) Untersuchungen mit $\mathbf{J}^{131}$-markiertem Globulin zur Frage der Abstammung der Liquoreiweisskörper, Klin. Wschr., 36: 857-863.

HARTER, D. H., M. D. YAHR AND E. A. KABAT (1962) Neurological disease with elevation of cerebrospinal fluid $\gamma$-globulin: a critical review, Trans. Amer. neurol. Ass., 87: 210-212.

HirschHorn, K., F. BaCh, R. L. Kolodory, I. L. Firschein and N. Hoshem (1963) Immune response and mitosis of human peripheral blood lymphocytes in vitro, Science, 142:1185-1187.

Hochwald, G. M. (1970) Influx of serum proteins and their concentration in spinal fluid along the neuraxis, J. neurol. Sci., 10: 269-278

HoCHWALD, G. M. AND M. WALLENSTEIN (1967a) Exchange of albumin between blood, cerebrospinal fluid and brain in the cat, Amer, J. Physiol., 212:1199-1204.

Hochwald, G. M. and M. C. Wallenstein (1967b) Exchange of $\gamma$-globulin between blood, cerebrospinal fluid and brain in the cat, Exp. Neurol., 19:115-126.

Janeway, C. A., F. S. Rosen, E. Merler and C. A. Alper (1967) The Gamma Globulins, Little Brown, Boston.

Kabat, E. A., M. Glusman and V. KNaUb (1948) Quantitative estimation of the albumin and $\gamma$ globulin in normal and pathologic cerebrospinal fluid by immunochemical methods, Amer. $J$. Med., 4: 653-662.

Kabat, E. A., D. H. Moore and H. Landow (1942) An electrophoretic study of the protein components in cerebrospinal fluid and their relationship to the serum proteins, J. clin. Invest., 21 : $571-577$

Kabat, E. A., D. A. Freedman, J. P. Murray and V. Knaub (1950) A study of the crystalline albumin, $\gamma$-globulin and total protein in the cerebrospinal fluid of 100 cases of multiple sclerosis and in other diseases, Amer.J.med. Sci., 219:55-64.

KATZMAN, R. (1968) The distribution of inulin and sucrose in the brain, evidence against the sink action of the CSF, Trans. Amer. neurol. Ass., 93:128-132.

Laterre, E. C. (1965) Les Protéines du Liquide Céphalorachidien à l'État normal et Pathologique, Arscia, Bruxelles.

LiNk, H. (1967) Immunoglobulin-G and low molecular weight proteins in human cerebrospinal fluid: Chemical and immunological characterization with special reference to multiple sclerosis, $A c t a$ neurol. scand., 43, Suppl. 28:1-136.

Lippincott, S. W., S. Korman, L. C. Lax And C. Corcoran (1965) Transfer rates of $\gamma$-globulin between cerebrospinal fluid and blood plasma (Results obtained on a series of multiple sclerosis patients), J.nucl. Med., 6:632-644.

Lowenthal, A. (1964) Agar Gel Electrophoresis in Neurology, Elsevier, Amsterdam.

Lowry, O. H., N. J. Rosebrough, A. L. Farr and R. J. Randall (1951) Protein measurement with the Folin phenol reagent, J. biol. Chem., 193: 265-275.

LumSden, C. E. (1965a) The proteins of cerebrospinal fluid in multiple sclerosis. In: D. MCAlPINE, C. E. Lumsden And E. D. ACheson, (Eds.), Multiple Sclerosis: A Reappraisal, Williams and Wilkins, Baltimore, Ch. 11, pp. 252-299, ref. 381-393.

Lumsden, C. E. (1965b) The clinical immunology of multiple sclerosis. In: D. MCAlPine, C. E. LUMSDEN AND E. D. ACHESON (Eds.), Multiple Sclerosis: A Reappraisal, Williams and Wilkins, Baltimore, Ch. 14, pp. 345-380, ref. 381--393. 
MCMenemey, W. H. (1961) Immunity mechanisms in neurological disease, Proc. roy. Soc. Med., 54 : $127-136$

OLDENDORF, W. H. (1967) Why is cerebrospinal fluid? Bull. Los Angeles neurol. Soc., 32:169-180.

Pérıer, O. AND A. Grégolre (1965) Electron microscopic features of multiple sclerosis lesions, Brain, 88: 937-952.

Rall, D. P. W. W. Oppelt and C. S. Patlak (1962) Extracellular space of brain as determined by diffusion of inulin from the ventricular system, Life Sci., 1 : 43-48.

Sandberg-Wollheim, M., O. Zettervall and R. Müller (1969) In vitro synthesis of IgC by cells from the cerebrospinal fluid in a patient with multiple sclerosis, Clin. exp. Immunol , 4: 401-405.

SCHINKo, H. AND H. Tschabitscher (1959) Der IgG-Quotient als differential-diagnostisches Kriterium zwischen Multipler Sklerose und degenerativen Erkrankungen des Nervensystems unter besonderer Berücksichtigung der Krankheitsdauer, Wien. klin. Wschr., 71:417-422.

Simpson, J. F., W. W. Tourtellotte, E. Kokmen, J. A. Parker and H. H. Itabashi (1969) Fluorescent protein tracing in multiple sclerosis brain tissue, Arch. Neurol. (Chic.), 20:373 -37?

Tourtellotte. W. W. (1970) Multiple sclerosis cerebrospinal fluid. In: P. J. Vinken AND G. W. BruYN (Eds.), Handbook of Clinical Neurology, Vol. 13 (Multiple Sclerosis), North-Holland Publ. Comp., Amsterdam.

Tourtellotte, W. W. AND J. A. Parker (1965) Distribution and subfractionation of immunoglobulins in patients with multiple sclerosis, Trans. Amer. neurol. Ass., S0: 107-112.

Tourtellotte, W. W. AND J. A. Parker (1966a) Multiple sclerosis: correlation between immunoglobulin-G in cerebrospinal fluid and brain, Science, 154: 1044-1046.

Tourtellotte, W. W. And J. A. Parker (1966b) Immunoglobulins in multiple sclerosis white matter, J. Neuropath. exp. Neurol., 25:167-169.

Tourtellotte, W. W. AND J. A. Parker (1967) Multiple sclerosis: Brain immunoglobulin-G and albumin, Nature (Lond.), 214: 683-686.

7 Ourtellotte, W. W. AND J. A. Parker (1968a) Postmortem evaluation of the blood brain barrier in multiple sclerosis, $J$. Neuropath. exp. Neurol., 27:159-163.

Tourtellotte, W. W. And J. A. Parker (1968b) Some spaces and barriers in postmortem muitiple sclerosis. In: A. LAJTHA AND D. H. FORD (Eds.), Brain Barrier Systems (Progress in Brain Research, Vol. 29), Elsevier, Amsterdam, New York.

Tourtellotte, W. W., H. H. Itabashi and J. A. Parker (1967) Multifocal areas of synthesis of immunoglobulin-G in multiple sclerosis brain tissue and the sink action of the cerebrospinal fiuid, Trans. Amer. neurol. Ass., 92: 288-290.

Tourtellotte, W. W., J. A. Parker and H. H. Itabashi (1966) Source of elevation of y-globulin in brain tissue from patients with multiple sclerosis, Trans. Amer. neurol. Ass., $91: 351$ - 352 .

Tourtellotte, W. W., A. F. Haerer, G. L. Heller and J. E. Somers (1964) Post-Lumbar Puncture Headaches, Thomas, Springfield, 111 .

Tourtellotte, W. W., J. A. Parker, R. B. Herndon and C. V. Cuadros (1968) Subacute sclerosing panencephalitis: Brain immunoglobulin-G, measles antibody and albumin, Neurology (Minneap.), 18:117-121.

TsCHIRGI, R. D. (1960) Chemical environment of the central nervous system. 11: Handbook of Physiology, Sect. 1 (Neurophysiology), Vol. 3, Amer. Physiol. Soc., Washington, D.C.

WIEME, R. J. (1965) Agar Gel Electrophoresis, Elsevier, Amsterdam.

YaHR, M. D., S. S. Goldensohn AND E. A. KaBAT (1954) Further studies on the gamma globulin content of cerebrospinal fluid in multiple sclerosis and other neurological diseases, Ann. $N$. $Y$. Acad.Sci., 58: 613-624. 